\title{
PENGEMBANGAN KEPRIBADIAN DAN KARAKTER SOSIAL PESERTA DIDIK MELALUI PEMBIASAAN DI PONDOK PESANTREN NURUL AMAL CIAMIS
}

\author{
ENTIN KURNIATIN
}

\begin{abstract}
Personality and social character relate to good and bad human behavior. Personality and social character are the basis for knowing oneself which can help a person to control his desires, protect himself from deviant behavior and direct his life towards goodness and harmony in behavior. The phenomenon of the emergence of various personality deviations and social characters among the younger generation is a problem that must be resolved immediately because it will lead to disharmony in the life of society and the nation. Pesantren is an educational institution that can be a solution to solving moral problems that occur. The education held at the pesantren is very relevant in developing the personality and social character of students so that they become Islamic individuals. The purpose of this study was to determine the planning, implementation, and results of personality development and social character through habituation at Nurul Amal Ciamis Islamic Boarding School. This research uses a qualitative approach. Data collection techniques are carried out through interviews, observation, and documentation. The validity of the data in this study used triangulation techniques. The data analysis technique used is descriptive narrative. Data collection procedures use data reduction techniques, data presentation, and conclusions. The results of this study indicate that the planning for the development of the personality and social character of students through habituation at the Nurul Amal Islamic Boarding School through the creation of curricula, program activities, preparation of teaching human resources, and the availability of supporting infrastructure. The implementation of personality and social character development is carried out by asatidz and asatidzah with habituation through annual, semester, monthly, daily and spontaneous programs. The personalities of students that are formed are the correct faith, correct worship, morality, independence, broad insight, in good health, regular in matters, guarding time, fighting lust, and beneficial to others. Meanwhile, the social characters that are formed are social care, environmental care, tolerance, communication, and responsibility.
\end{abstract}

Keywords: Personality, social character, students, habit 


\section{Pendahuluan}

Kepribadian dan karakter sosial merupakan unsur utama dalam menjaga keberlangsungan kehidupan, menciptakan harmonisasi, dan pencapaian kemajuan suatu bangsa. Kepribadian dan karakter sosial berkaitan erat dengan perilaku baik dan buruk manusia. Pemahaman kepribadian dan karakter sosial menjadi landasan untuk mengenal diri sendiri yang dapat membantu seseorang agar dapat mengendalikan hawa nafsunya, memelihara dirinya dari penyimpangan serta mengarahkan hidupnya menuju kebaikan dan keserasian dalam berperilaku.

Islam adalah dien yang memberikan perhatian besar terhadap pengembangan kepribadian dan karakter sosial seseorang. Hal ini karena Islam bukan saja ajaran normatif yang diyakini, tetapi Islam mesti terwujud dalam kehidupan nyata pemeluknya. Oleh sebab itu, ajaran yang diyakini dalam Islam harus tercermin pada sikap dan perilaku pribadi-pribadi muslim.

Kepribadian dan karakter yang baik menurut Islam dicirikan apabila seseorang memiliki aqidah, akhlak, perilaku, pemikiran, dan amaliyah yang sesuai dengan Al-Qur'an dan Sunnah Nabi Muhammad Saw. Dengan demikian aqidah, akhlak, perilaku, pemikiran, dan amaliyah yang tidak berdasarkan AlQur'an dan Sunnah, akan menimbulkan penyimpangan kepribadian dan karakter. Hal ini mendorong manusia terjerumus pada derajat yang hina sehingga kehidupan pun akan mengalami kekacauan.

Allah Swt. telah mengutus manusia terbaik yakni Nabi Muhammad Saw. sebagai model dan teladan utama bagi seluruh muslim, sebab segala kesempurnaan manusia ada pada diri beliau. Allah Swt. berfirman dalam QS. Al-Ahzab ayat 21:

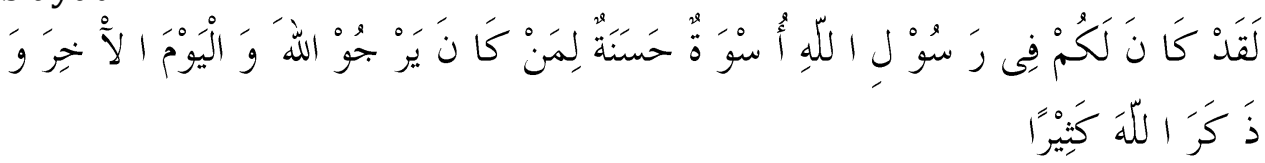

"Sesungguhnya telah ada pada (diri) Rasulullah itu uswatun hasanah (suri teladan yang baik) bagimu (yaitu) bagi orang yang mengharap (rahmat) Allah dan (kedatangan) hari kiamat dan dia banyak menyebut Allah." (QS. AlAhzaab: 21). (Kementrian Agama, 2007)

Rasulullah Saw. memiliki kepribadian multidimensi yang terepresentasikan dalam semua sisi kehidupannya. Oleh karena itu, sebagai seorang muslim selayaknya menjadikan Rasulullah Saw. sebagai teladan dalam berbagai aspek kehidupan termasuk akhlak dan perilakunya.

Mencetak individu yang berkepribadian dan berkarakter baik sesuai kehendak negara dan agama, merupakan langkah awal dalam membentuk masyarakat atau bangsa yang baik. Karena individu adalah unit terkecil dari sebuah komunitas, maka membentuk individu yang berkualitas merupakan prioritas utama. Ketika individu-individu yang shalih telah terwujud, maka akan terbentuk masyarakat yang shalih. Masyarakat shalih merupakan cikal 
bakal terwujudnya negara yang baldatun toyyibatun wa rabbun ghofur atau dapat membentuk masyarakat madani.

Fakta dan realitas sekarang ini, telah terjadi pergeseran nilai kepribadian dan karakter yang berdampak pada munculnya berbagai permasalahan yang mengancam keharmonisan interaksi sosial di lingkungan keluarga, lembaga pendidikan, dan masyarakat. Tindakan amoral dilakukan oleh oknum generasi muda, khususnya pelajar.

Berdasarkan hasil pengawasan Komisi Perlindungan Anak Indonesia (KPAI) selama rentang bulan Januari sampai April 2019 telah terjadi kekerasan terhadap anak dalam bentuk bullying sebanyak 37 kasus dengan rincian 25 kasus terjadi dijenjang pendidikan SD, jenjang SMP sebanyak 5 kasus, jenjang SMA sebanyak 6 kasus, dan 1 kasus terjadi di jenjang perguruan tinggi (https://news detik.com edisi 02 Mei 2019, Diakses tanggal 6 April 2020).

Tawuran antar pelajar merupakan fenomena yang belum dapat diselesaikan. Berdasarkan data Komisi Perlindungan Anak Indonesia (KPAI) angka tawuran di Indonesia pada tahun 2017 sebanyak 12,9\% dan meningkat menjadi 14\% pada tahun 2018 (https://surabaya.tribunnews.com edisi 22 September 2019. Diakses tanggal 6 April 2020).

Badan Narkotika Nasional (BNN) melaporkan hasil survey tahun 2019 tentang penyalahgunaan narkoba yaitu mencapai 3,6 juta orang. Data menunjukan pengguna terbanyak adalah usia 15-65 tahun. Jumlah ini meninggkat 0,03\% dari tahun 2018 (https://liputan6.com edisi 5 Desember 2019. Diakses tanggal 6 April 2020).

Data yang dilaporkan oleh Survey Demografi dan Kesehatan Indonesia (SDKI) sangat mencengangkan. Sekitar 2\% remaja wanita dan 8\% remaja lakilaki pada rentang usia 15-24 tahun telah melakukan hubungan seksual sebelum menikah. Fenomena ini berdampak pada semakin meningkatnya penderita HIV/AIDS. Kementrian Kesehatan RI melaporkan pada tahun 2019 terdapat 117.064 kasus AIDS dan 349.882 kasus HIV positif dan Indonesia adalah 1 dari 20 negara yang kontribusi HIV terbanyak di dunia (https://Health detik.com edisi 9 Oktober 2018. Diakses tanggal 7 April 2020).

Deretan kasus yang telah dipaparkan di atas merupakan indikasi lunturnya kepribadian dan karakter anak bangsa. Jika tidak ditangani serius, kasus-kasus tersebut akan semakin meningkat dari waktu ke waktu. Kehidupan masyarakat akan mengalami disharmonisasi, kejahatan merajalela dan dampak yang sangat mengkhawatirkan adalah terjadinya kemunduran peradaban bangsa.

Apabila kita cermati, masalah bergesernya nilai-nilai kepribadian dan karakter khususnya karakter sosial berkaitan erat dengan dunia pendidikan. Tampak ada kesenjangan antara pendidikan yang merupakan sarana untuk mencetak sumber daya manusia berkualitas dengan kenyataan peserta didik sebagai outputnya. Pendidikan agama dan moral yang diberikan di sekolah 
belum sepenuhnya membentuk peserta didik menjadi pribadi yang sempurna. Ilmu pengetahuan modern belum berhasil membentuk kepribadian peserta didik pada sisi akhlak dan ruhaninya.

Pesantren merupakan salah satu lembaga pendidikan Islam yang berupaya menyelesaikan permasalahan jaman dengan memberikan pendidikan terbaik bagi peserta didiknya. Pesantren dapat merealisasikan misi suci Islam dalam membentuk sosok muslim yang memiliki kepribadian Islami dan karakter sosial yang diinginkan. Pesantren sangat relevan dalam melakukan pembinaan untuk mencetak peserta didik yang cerdas, berkepribadian baik, dan berkarakter sosial.

Salah satu pondok pesantren yang memiliki kontribusi dalam upaya mencetak kader bangsa yang memiliki kepribadian dan karakter sosial yang baik dan Islami adalah Pondok Pesantren Nurul Amal Ciamis. Pesantren Nurul Amal melakukan pendidikan, pembinaan, dan pengasuhan dalam rangka mengembangankan kepribadian dan karakter sosial peserta didik melalui pembiasaan berbagai aktivitas kebaikan, sehingga diharapkan dapat membentuk generasi Qur'ani.

\section{Kajian Teori}

Konsep Pengembangan

Pengertian pengembangan dalam Kamus Umum Bahasa Indonesia karya Poewadarminta (2007) adalah perbuatan menjadikan bertambah, berubah sempurna (pikiran, pengetahuan dan sebagainya). Dalam bahasa Inggris pengembangan merupakan terjemahan dari kata development, yang berarti perkembangan terakhir atau keadaan baru dalam suatu perkara (Echols \& Shadily, 2003). Nata (2012) berpendapat bahwa pengembangan terkait dengan upaya memperbaiki, meningkatkan dan memajukan suatu kegiatan dari keadaan yang kurang maju kepada keadaan yang lebih maju. Berdasarkan penjelasan tersebut dapat difahami bahwa pengembangan yaitu upaya atau proses untuk menjadikan suatu hal menjadi lebih baik, maju, meningkat dan sempurna.

Konsep Kepribadian

Kepribadian merupakan kekhasan seseorang dalam perilaku, berpikir, dan merespon terhadap keadaan. Kepribadian erat kaitannya dengan citra diri seseorang. Menurut Maharani (2018) kepribadian merupakan bagian dari individu yang mencerminkan atau mewakili pribadi yang bersangkutan. Kepribadian bukan sekedar membedakan individu tersebut dari orang lain, namun yang lebih penting adalah itulah cermin dia sebenarnya.

Kepribadian dalam Islam dikenal dengan syakhshiyah Islamiyyah. Menurut Hidayat et al.. (2018) penggunaan istilah ini telah menjadi kesepakatan umum dalam menggambarkan kepribadian Islam. Selain syakhshiyah, kepribadian juga dikenal dengan nafsiyah. Asal kata syakhshiyah adalah syakhsh sedangkan asal kata nafsiyah adalah nafs yang kedua-duanya 
merujuk pada makna pribadi. Untuk menunjukan arti kepribadian, istilah nafsiyah lebih banyak digunakan dalam teks Al-Qur'an dan Hadits dari pada istilah syakhshiyah. Namun dalam kajian psikologi keislaman, kata nafsiyah lebih sedikit digunakan disebabkan kata nafs memiliki multi makna. Selain bermakna kepribadian, nafs juga mengandung makna nyawa, ghadhab, dan syahwat (Helmy, 2019).

Berdasarkan penjelasan di atas, kepribadian dapat dirumuskan sebagai keseluruhan perilaku, watak khas yang tampak dan menjadi ciri khas seseorang yang merupakan cerminan dirinya dan membedakannya dengan orang lain. Sedangkan kepribadian Islam adalah hasil integrasi fitrah nafsani (akal, kalbu, nafsu) yang dituntun oleh nilai-nilai Islam sebagai manifestasi dari kepatuhan kepada Allah Swt. dan terefleksi dalam perilaku khas seseorang.

Kepribadian terbentuk dari id, ego, dan super ego. Ketiga unsur ini merupakan bentukan dari pengalaman masa lalu yang menjadi karakter (Silahudin, 2019). Islam memandang, unsur kepribadian ditentukan dengan tidak mengesampingkan pembahasan tentang substansi manusia.

Unsur pembentuk kepribadian manusia terdiri dari jasad, kalbu, akal, dan nafsu/nafsiyah (Hidayat et al., 2018). Silahudin (2019) menyatakan bahwa kepribadian dipengaruhi oleh unsur yang ada dalam diri manusia dan unsur yang ada di luar diri manusia. Indera, akal, otak, dan nafsiyah merupakan unsur dalam diri. Unsur yang berasal dari luar diri antara lain realitas/fakta dan informasi awal berupa ilmu pengetahuan. Hidayat (2018) berpendapat bahwa kepribadian dipengaruh oleh faktor lingkungan, pendidikan, dan pengalaman hidup.

Az-Zatani (1994) mengemukakan kepribadian dipengaruhi oleh tiga faktor utama, yakni faktor internal (individu), faktor eksternal (lingkungan) dan faktor tekad dan perbaikan diri. Menurut Nata (2012) beberapa aliran pendidikan memiliki perbedaan pendapat tentang faktor-faktor yang mempengaruhi kepribadian manusia. Aliran empirisme (lahir) menyatakan yang berperan membentuk pribadi manusia adalah lingkungannya, bukan pembawaannya. Aliran nativisme (bathin) berpendapat bahwa kepribadian dipengaruhi oleh pembawaan bukan lingkungan. Sedangkan aliran konvergensi menyatakan bahwa pembawaan dan lingkungan berpengaruh pada kepribadian seseorang. Pada intinya aliran empirisme, nativisme, dan konvergensi berprinsip bahwa kepribadian dibentuk oleh usaha manusia. Berbeda dengan ketiga aliran tersebut, kepribadian dalam pandangan Islam pada intinya hasil perpaduan antara usaha manusia dan pertolongan atau hidayah Allah Swt. (Nata, 2012).

Berdasarkan penjelasan di atas, kepribadian seseorang dipengaruhi oleh faktor bawaan (individu), lingkungan, tekad dan perbaikan diri serta petunjuk/hidayah Allah Swt. 
Pada proses pertumbuhan seseorang, kepribadian dapat mengalami perubahan sebab kepribadian bersifat dinamis. Seseorang dapat memiliki kepribadian yang lebih baik dengan adanya pendidikan dan pengkondisian lingkungan. Menurut Idris dan Usman (2019) pendidikan berpengaruh signifikan terhadap pengembangan kepribadian peserta didik. Hutagalung (2007) menuliskan bahwa kepribadian selalu berkembang dan berubah, melibatkan kerja tubuh dan jiwa, sifat khas individu, dan kepribadian mampu beradaptasi dengan lingkungan.

Upaya pengembangan kepribadian harus dilakukan sejak anak berusia dini. Pada saat anak-anak masih kecil, pikiran dan perilakunya lebih banyak dipengaruhi oleh orang-orang yang ada disekitarnya. Maka daripada itu, pembiasaan berperilaku baik harus dibiasakan sedini mungkin karena akan berpengaruh pada kepribadiannya. Peran orang tua sangat penting dalam pengembangan kepribadian anak. Oleh karena itu, idealnya penanaman nilainilai fundamental untuk membentuk kepribadian telah terlaksana secara kokoh di dalam keluarga yang merupakan institusi pendidikan pertama bagi setiap orang.

Konsep Karakter Sosial

Karakter selalu berhubungan dengan baik dan buruk. Seseorang yang berperilaku pendusta, rakus, dan kejam dikatakan sebagai orang yang memiliki karakter buruk, sedangkan seorang yang berperilaku jujur, penolong, dan pemurah dikatakan sebagai orang yang memiliki karakter baik/mulia.

Menurut Zubaedi (2011) karakter berarti to mark (menandai) yakni memfokuskan, atau mengaplikasikan berbagai nilai kebaikan dalam suatu bentuk tindakan atau tingkah laku. Karakter seperti yang diungkapkan oleh Anwar dan Salim (2019) didefinisikan sebagai suatu tindakan yang timbul tanpa pemikiran sebab telah tertanam dalam pikiran. Menurutnya fokus pendidikan karakter ialah pada beberapa tujuan etika dan prakteknya meliputi pengokohan kecakapan-kecakapan yang penting, mencakup perkembangan sosial peserta didik. Rahim dan Setiawan (2019) mengemukakan bahwa karakter individu dimaknai sebagai hasil keterpaduan empat bagian, yakni olah hati, olah fikir, olah raga, olah rasa dan karsa.

Berbicara tentang karakter, maka terkandung makna karakter sosial. Kata sosial dalam Kamus Umum Bahasa Indonesia berarti berkenaan dengan masyarakat, suka memperhatikan kepentingan umum (suka menolong, menderma, dan sebagainya) (Poerwadarminta, 2007). Kata sosial mengandung arti segala perilaku manusia yang mencerminkan hubungan non individualis. Biasanya istilah tersebut disandingkan dengan kehidupan keseharian manusia dan kelompok masyarakat. Dengan demikian pengertian sosial merujuk pada hubungan manusia dengan manusia, hubungan manusia dengan masyarakat, hubungan manusia dengan kelompok tertentu, dan hubungan manusia dengan organisasi sebagai wadah untuk mengembangkan dirinya. 
Karakter sosial yaitu seluruh tingkah laku individu yang memiliki kecenderungan tertentu dalam berinteraksi dengan berbagai situasi (Wardati, 2019). Hal ini dapat dikatakan bahwa setiap individu memiliki cara berperilaku yang khas seperti sikap, adat, bakat, kebiasaan, kecakapan, dan tindakan yang relatif sama setiap hari. Karakter sosial menurut Tetep (2017) erat kaitannya dengan interaksi antar individu atau peserta didik tentang bagaimana dia memiliki kemampuan agar dapat hidup bersama dengan lingkungan sebayanya, orang tua serta lingkungan masyarakat secara luas.

Pendidikan karakter sangat efektif dilakukan pada usia 6-11 tahun sebab pada usia ini, perkembangan motorik anak sangat pesat, tak terkecuali perkembangan kepribadian, budi pekerti, bahasa, emosional juga intelektual Shoimah, et al. (2018). Amrah (2018) menjelaskan, pendidikan karakter berpedoman pada nilai etika, seperti kepedulian, keadilan, kejujuran, tanggung jawab, serta menghormati diri sendiri juga orang lain. Pengembangan karakter sosial sangat penting dalam membentuk peserta didik agar memiliki kemampuan hidup bersama, aman, tertib, nyaman dengan toleransi yang tinggi sehingga akan menciptakan masyarakat demokratis (Tetep, 2017).

Rahim dan Setiawan (2019) mengemukakan hasil penelitiannya bahwa karakter sosial dapat dikembangkan melalui pembiasaan dalam akhlak dan ibadah. Adapun karakter sosial yang terbentuk yakni bersahabat, komunikatif, peduli lingkungan, dan peduli sosial. Penanaman nilai kebaikan melalui pembiasaan oleh pendidik atau guru berdampak pada pembentukan perilaku sosial yakni peduli, kebersamaan, serta toleransi (Maharani, 2018). Tetep (2017) berpendapat karakter sosial menanamkan kepribadian kepada individu agar mempunyai berbagai nilai seperti solidaritas, loyalitas, demokratis, damai, rela berkorban dan sebagainya.

Seperti juga kualitas diri yang lainnya, karakter sosial tidak berkembang sendiri. Perkembangan karakter sosial pada setiap individu dipengaruhi oleh faktor bawaan dan faktor lingkungan. Faktor bawaan (genetika) yakni segala hal yang telah dibawa sejak lahir, baik yang bersifat fisik maupun kejiwaan (Tetep, 2017). Faktor lingkungan adalah sesuatu yang berada di luar individu.

Konsep Peserta Didik

Peserta didik merupakan salah satu komponen dalam dunia pendidikan. Peserta didik berkedudukan sebagai objek sekaligus subjek. Undang-undang Republik Indonesia No. 20 tahun 2003 pasal 1 tentang sistem pendidikan nasional menyatakan bahwa peserta didik yaitu anggota masyarakat yang berusaha mengembangkan potensi diri melalui proses pembelajaran yang tersedia pada jalur, jenjang, dan jenis pendidikan tertentu. Nata (2012) menjelaskan tentang peserta didik dalam pandangan Islam, yakni individu yang sedang tumbuh dan berkembang, baik secara fisik, psikologis, sosial, dan religius dalam mengarungi kehidupan di dunia dan akhirat kelak. 
Secara etimologi peserta didik adalah anak didik yang mendapat pengajaran ilmu. Adapun secara terminologi peserta didik yaitu anak didik atau individu yang mengalami perubahan, perkembangan sehingga masih memerlukan bimbingan dan arahan dalam membentuk kepribadian serta sebagai bagian dari struktural proses pendidikan (Al-Hamdani, 2018).

Hidayat (2018) menggunakan kata murid untuk peserta didik. Menurut pendapatnya, istilah murid lebih dekat dengan ciri khas keislaman. Murid mengandung makna kesungguhan dalam belajar, keberkahan, serta memuliakan guru dan ilmu. Istilah murid merupakan khas pengaruh agama Islam yang dikenalkan oleh para shufi (Tafsir, 2016).

Berdasarkan pendapat para ahli di atas, peserta didik adalah anak didik yang merupakan obyek dan subyek pendidikan yang sedang tumbuh dan berkembang, baik secara fisik, psikologis, sosial, dan religius sehingga masih memerlukan bimbingan dan arahan dalam membentuk kepribadiannya.

\section{Konsep Pembiasaan}

Pembiasaan merupakan salah satu metode Islam dalam mendidik anak. Pembiasaan cukup efektif dalam membentuk kepribadian dan karakter, terutama bagi anak-anak. Pembiasaan merupakan metode pendidikan yang jitu, dan besar pengaruhnya terhadap kepribadian seseorang (Tafsir, 2016). Menurut Cahyaningrum et al. (2017) Pendidikan pada anak usia dini merupakan salah satu upaya unuk merangsang berbagai potensi yang dimiliki anak supaya dapat berkembang dengan optimal. Pembiasaan merupakan pendidikan praktis sebab peserta didik secara langsung melakukan ucapan atau perbuatan tertentu agar menjadi terbiasa.

Pembiasaan berasal dari kata dasar biasa. Setelah mendapat imbuhan pe- -an, menjadi pembiasaan yang memiliki makna suatu proses. Sehingga pembiasaan adalah suatu proses yang membentuk sesuatu/seseorang menjadi terbiasa (Poerwadarminta, 2007). Pembiasaan bermakna lazim, umum, seperti sediakala, atau sudah merupakan hal yang tidak terpisahkan dari kehidupan sehari-hari.

Menurut Tafsir (2016) pembiasaan sebenarnya berintikan pengalaman dan pengulangan. Pembiasaan adalah sesuatu yang diamalkan sehingga melatih kebiasaan-kebiasan yang baik. Menurut Supiana et al. (2019) metode pembiasan memiliki ciri yaitu pengulangan suatu aktivitas yang sama secara berkali-kali. Pengulangan tersebut sengaja dilakukan agar asosiasi antara stimulus dan respon menjadi sangat kuat. Mengulang adalah sebagian reinforcement (peneguhan) (Tafsir, 2016).

Rusmaini (2017) berpendapat bahwa nilai-nilai karakter dapat diinternalisasikan melalui pembiasaan dalam kehidupan sehari-hari seperti tenggang rasa, kejujuran, keadilan, sabar dan kebersihan. Menurut Fuad (2019) pembiasaan diri ialah melakukan suatu aktivitas yang baik atau keterampilan secara kontinyu dan konsisten dalam kurun waktu yang cukup lama, sehingga akan menjadi kebiasaan yang sulit ditinggalkan. 
Anak-anak belum memiliki kesadaran tentang baik dan buruk. Pembiasaan dinilai efektif diterapkan terhadap peserta didik yang berusia kanak-kanak. Sebab anak kecil memiliki rekaman ingatan yang kuat. Anakanak memiliki kecendrungan fitrah pada kebaikan sehingga pembiasaan kebaikan dipusatkan pada usia dini (Ulwan, 1984). Menarik apa yang diungkapkan oleh Al-Hamdani (2018) bahwa sesuatu yang telah dibiasakan sedari kecil akan membentuk kepribadian seseorang yang muncul dalam bentuk tingkah laku, cara berpikir, tutur kata, serta falsafah hidupnya.

Utami (2019) menjelaskan pendidikan dengan pembiasaan dapat diselenggarakan secara terprogram dalam pembelajaran atau secara tidak terprogram melalui kegiatan sehari-hari. Pembiasaan yang terprogram dalam pembelajaran dilaksanakan dengan suatu perencanaan khusus dalam jangka waktu tertentu dalam rangka mengembangkan kepribadian peserta didik secara individu, kelompok, atau klasikal. Sedangkan pembiasaan secara tidak terprogram dapat dilakukan melalui kegiatan rutin secara terjadwal.

Hal ini senada dengan Rahim dan Setiawan (2019) yang menuliskan hasil penelitiannya bahwa pembiasaan yang dilakukan secara terprogram setiap hari baik dalam kegiatan belajar, aktivitas keseharian maupun kegiatan ekstrakurikuler akan membentuk karakter positif peserta didik. Menurut Sugiharto (2017) pengembangan karakter dapat dilakukan dengan pembiasaan akhlak dan pembiasaan beribadah.

Tujuan pembiasan ialah agar peserta didik melakukan sikap-sikap dan kebiasaan baru yang tepat dan positif sesuai dengan ruang dan waktu (Supiana et al., 2019). Melalui metode pembiasaan, peserta didik dilatih agar mampu membiasakan diri berperilaku baik dalam berbagai kondisi, kapan saja, dengan siapa saja dan dimana saja (Anwar \& Salim, 2019).

Lathifah dan Rusli (2019) berpendapat bahwa metode pembiasaan menjadikan peserta didik melakukan sesuatu dengan suka rela tanpa keterpaksaan. Metode pembiasaan dalam penanaman akhlak atau karakter dan beribadah, merupakan salah satu upaya pengembangan kepribadian yang cukup efektif sehingga menjadi aktivitas reflek seorang peserta didik. Membiasakan anak mengucapkan salam ketika bertemu saudara muslim secara kontinyu, akan menjadikan peserta didik secara sepontan mengucapkan salam ketika bertemu orang lain.

Hasil penelitian Haerudin et al. (2019) menunjukan pendidikan karakter melalui pembiasaan yang baik, penanaman moral, dan penanaman nilai-nilai religius, efektif membentuk karakter peserta didik. Adapun karakter yang terbentuk antara lain religius, kemandirian, kejujuran, kedisiplinan, kerja keras, peduli sesama, peduli lingkungan, kreatif, toleransi, bersahabat, dan bertanggungjawab. 


\section{Metode}

Penelitian mengenai pengembangan kepribadian dan karakter sosial melalui pembiasaan di Pondok Pesantren Nurul Amal Ciamis ini menggunakan jenis penelitian studi kasus. Penelitian bertujuan untuk mengetahui perencanaan, pelaksanaan, dan hasil pengembangan kepribadian dan karakter sosial peserta didik melalui pembiasaan yang dilakukan di Pondok Pesantren Nurul Amal Ciamis.

Pendekatan yang digunakan dalam penelitian ini adalah pendekatan kualitatif. Penelitian kualitatif merupakan suatu paradigma penelitian untuk mendeskripsikan peristiwa, perilaku orang atau suatu keadaan pada tempat tertentu secara terperinci dan mendalam dalam bentuk narasi. Penelitian kualitatif menekankan pada quality atau hal yang terpenting dari sifat suatu barang atau jasa berupa fenomena/kejadian/gejala sosial dimana makna dibalik kejadian tersebut dapat dijadikan pelajaran berharga bagi suatu perkembangan konsep teori (Satori \& Komariah, 2009).

Penelitian ini bermaksud untuk memahami fenomena peserta didik yang ada di Pondok Pesantren Nurul Amal Ciamis berupa perilaku, persepsi, dan tindakan serta mendeskripsikan dalam bentuk bahasa atau kata-kata. Teknik analisis data yang digunakan adalah deskriptif naratif. Prosedur pengumpulan data dalam penelitian ini menggunakan tiga teknik, yaitu reduksi data, penyajian data, penarikan kesimpulan dan verifikasi

\section{Hasil dan Pembahasan}

\section{Profil Ponpes Nurul Amal Ciamis}

Pondok Pesantren Nurul Amal Ciamis adalah sebuah lembaga pendidikan Islam yang mengkhususkan para peserta didiknya dalam kegiatan menghafal Al-Qur'an. Selain menghafal, para peserta didik juga dibekali dengan materi-materi penunjang seperti ilmu tajwid dasar, hadits-hadits pilihan, doa-doa, dan pembiasaan akhlak karimah. Peserta didik Ponpes Nurul Amal terdiri dari laki-laki dan perempuan yang berusia 7-12 tahun. Ponpes Nurul Amal beralamat di jalan Bojongmengger-Cimaragas, Rt 04 Rw 17 Dusun Cikawung, Desa Bojongmengger, Kecamatan Cijeungjing, Kabupaten Ciamis, Jawa Barat-Indonesia. Ponpes Nurul Amal memiliki visi "Menjadi sebuah lembaga pendidikan Islam yang mencetak generasi Qur'ani". Sedangkan misi Ponpes Nurul Amal adalah: 1). Melalui program hafalan, mendidik anak agar mencintai Al-Qur'an. 2). Pengintegrasian ilmu pengetahuan dengan Al-Qur'an. 3). Pengamalan nilai-nilai Al-Qur'an sejak dini.

Perencanaan Pengembangan Kepribadian dan Karakter Sosial Peserta Didik di Ponpes Nurul Amal

Pengembangan kepribadian dan karakter sosial di Ponpes Nurul Amal bertujuan untuk mencetak peserta didik menjadi generasi Qur'ani. Adapun karakteristik generasi Qur'ani yaitu 1) aqidah yang benar, 2) ibadah yang benar, 3) akhlakul karimah, 4) berbadan sehat 5) berwawasan luas 6) 
melawan hawa nafsu, 7) menjaga waktu, 8) teratur dalam segala urusan, 9) mandiri, dan 10) bermanfaat bagi orang lain. Sedangkan karakter sosial yang terbentuk adalah peduli sosial, peduli lingkungan, toleransi, komunikatif, dan tanggung jawab.

Pengembangan kepribadian dan karakter sosial di Ponpes Nurul Amal diawali dengan perencanaan yang didasari oleh visi misi pesantren. Selanjutnya dibuatlah kurikulum, program, rencana pembelajaran, dan tata tertib. Selain itu perencanaan pengembangan kepribadian dan karakter sosial di Ponpes Nurul Amal melalui penyiapan SDM pendidik dan penyediaan sarana prasarana.

Pelaksanaan Pengembangan Kepribadian dan Karakter Sosial Peserta Didik di Ponpes Nurul Amal

Tahap berikutnya setelah perencanaan adalah pelaksanaan. Pengembangan kepribadian dan karakter sosial di Ponpes Nurul Amal Ciamis dilakukan melalui pembiasaan. Metode pembiasaan dipilih karena sangat efektif untuk mengembangkan kepribadian dan karakter sosial pada usia dini.

Adapun pembiasaan-pembiasaan yang dilakukan di Ponpes Nurul Amal dalam pengembangan kepribadian dan karakter sosial peserta didik yaitu:

1) Pembiasaan dalam akidah yang benar

Pembiasaan untuk menanamkan akidah yang benar pada peserta didik di Ponpes Nurul Amal yaitu dengan membimbing peserta didik untuk menjalankan perintah Allah Swt. seperti melaksanakan shalat wajib, melaksanakan shalat sunnah, menghafal ayat-ayat Al-Qur'an, menghafal hadits-hadits, wirid setelah shalat, serta pemberian arahan dan penguatan-penguatan oleh asatidz/asatidzah tentang keikhlasan, pengenalan terhadap Allah Swt. dan lain sebagainya.

2) Pembiasaan dalam ibadah yang benar

Agar dapat melakukan ibadah yang benar sesuai Rasulullah Saw., peserta didik di Ponpes Nurul dibiasakan untuk melaksanakan tata cara ibadah wajib dan sunnah, seperti shalat lima waktu, shalat rawatib, shaum wajib, shaum sunnah Senin Kamis, shaum yang bersifat tahunan (shaum Arafah dan shaum Assyura), dzikir dan berdo'a setelah shalat, dzikir alMa'tsurat pagi dan sore, berdoa setiap mengawali aktivitas, shalat duha, shalat tahajud, infak shodaqoh, melaksanakan shalat gerhana, shalat istisqa, dan shalat jenazah.

3) Pembiasaan dalam akhlakul karimah

Agar memiliki akhlak yang baik, peserta didik di Ponpes Nurul Amal dibiasakan dengan akhlak-akhlak terpuji sesuai dengan yang dicontohkan oleh Rasulullah Saw. Seperti menyayangi yang muda, menghormati yang tua, tidak mengejek, tidak mencela, tidak membuli, saling menghargai, berkata sopan, hormat kepada guru, tidak berkata lebih keras dari suara guru, tidak takabur, menyebarluaskan salam, rendah hati, tidak mencibir, tidak memotong pembicaraan orang lain. 


\section{4) Pembiasaan mandiri}

Karakter mandiri merupakan karakter dimana seseorang tidak tergantung kepada orang lain. Karakter tersebut sangat dibutuhkan agar peserta didik mampu berdiri sendiri dan memiliki harga diri dalam menjalankan kehidupannya. Pembiasaan untuk mengembangkan kepribadian mandiri antara lain peserta didik dilatih untuk mandi sendiri, mencuci alat makan sendiri, merapiakan tempat tidur, menjaga kebersihan, merapikan handuk, merapikan lemari, menyimpan pakaian kotor di keranjang, dan tidak manja.

5) Pembiasaan dalam berwawasan luas

Dalam Islam, seluruh perbuatan yang kita lakukan harus dimulai dengan aktifitas berpikir. Oleh karena itu, seorang muslim harus memiliki wawasan keislaman dan keilmuan yang luas. Pembiasaan berwawasan luas di Ponpes Nurul Amal dilakukan dengan program membaca, menonton tayangan film-film ilmu pengetahuan dan sejarah $\mathrm{Nabi}$, serta pemberian informasi tentang dunia Islam.

6) Pembiasaan agar berbadan yang sehat

Seorang muslim yang kuat lebih dicintai Allah Swt. dari pada muslim yang lemah. Untuk mewujudkan muslim yang kuat fisiknya, Ponpes Nurul Amal melaksakan kebiasaan menjaga kebersihan dan menjaga kesehatan seperti dibiasakan untuk menjaga kebersihan diri dengan mandi 2 kali sehari, menggosok gigi, memakai pakaian yang bersih, olahraga, makan makanan yang baik dan halal, manjauhi tempat yang kotor dan berbahaya.

7) Pembiasaan dalam melawan hawa nafsu

Melawan hawa nafsu merupakan salah satu jihad yang harus dilakukan oleh setiap muslim. Muslim yang dapat mengendalikan hawa nafsunya, akan senantiasa mengarahkan perilakunya pada hal-hal yang disukai oleh Allah Swt. Pembiasaan agar dapat melawan hawa nafsu dilakukan dengan membuat jadwal yang teratur, mengetahui yang halal dan haram, dan pembuatan aturan.

8) Pembiasaan dalam menjaga waktu

Pandai menjaga waktu merupakan faktor penting bagi seorang muslim. Hal ini dikarenakan waktu mendapat perhatian yang begitu besar dari Allah Swt. dan Rasul-Nya. Pembiasaan dalam menjaga waktu dilakukan dengan adanya jadwal harian yang disusun secara terprogram, maka peserta didik akan terbiasa dengan menjaga waktu dan menggunakan waktu sebaikbaiknya.

9) Pembiasaan teratur dalam urusan

Teratur dalam suatu urusan merupakan kepribadian seorang muslim yang diarahkan oleh Al-Qur'an maupun sunnah. Sehingga didalam hukum Islam, baik yang terkait dengan ubudiyah maupun muamalah selayaknya diselesaikan dan dilaksanakan dengan amal terbaik. Pembiasaan teratur dalam urusan di Ponpes Nurul Amal dilakukan dengan memperbaiki penampilan, 
bersemangat dalam urusan, memanfaatkan waktu untuk kebaikan, tidak menyianyiakan waktu, dan rela berkorban.

10) Pembiasaan dalam bermanfaat bagi orang lain

Bermanfaat bagi orang lain merupakan sebuah tuntutan bagi setiap muslim. Manfaat yang dimaksud yakni manfaat yang baik sehingga di manapun dia berada, orang disekitarnya merasakan kemanfaatannya. Pembiasaan-pembiasaan perilaku agar dapat bermanfaat bagi orang lain tampak pada kebiasaan peserta didik yang ditunjukkan dengan munculnya rasa empati kepada orang lain dan dia dapat memberikan bantuan secara sadar tanpa ada perintah dari siapapun, juga melaksanakan hak orang lain, tolong menolong, ceria, loyal, mengajarkan teman membaca Al-Qur'an dengan baik, mengajari teman tentang pelajaran tertentu, kegiatan kebersihan di lingkungan masyarakat, pemberian bantuan kepada tetangga yang kurang mampu, dan berbagi makanan kepada teman.

Selain pembiasaan untuk mengembangkan kepribadian, Ponpes Nurul Amal juga mengembangkan karakter sosial bagi peserta didiknya. Pembiasaan untuk mengembangkan karakter sosial, yaitu:

11) Pembiasaan peduli sosial

Manusia diciptakan dengan fitrah harus hidup bersama dan membutuhkan orang lain. Setiap manusia pasti mempunyai berbagai kepentingan antara satu dengan yang lainnya, sehingga akan terjalin interaksi. Pembiasaan peduli sosial dilakukan dengan membiasakan peserta didik untuk memberikan bantuan dalam bentuk materi dan non materi kepada sesama muslim (infak dan sodaqoh), baik yang ada di dalam maupun di luar lingkungan pesantren.

12) Pembiasaan peduli lingkungan

Karakter peduli lingkungan merupakan suatu sikap yang melekat pada diri seseorang yang berupaya untuk mengelola dan memperbaiki lingkungan sekitar secara benar sehingga lingkungan tersebut dapat dinikmati terus menerus tanpa merusak keadaannya. Pembiasaan yang dilakukan agar peserta didik memiliki kepedulian terhadap lingkungan adalah menjaga kebersihan dan kerapian asrama, membuang sampah pada tempat sampah, menjaga fasilitas umum (pesantren), kerja bakti membersihkan jalan masyarakat.

\section{3) Pembiasaan toleransi}

Toleransi adalah tindakan dan sikap yang menghargai keragaman agama, suku, etnis, sikap, pendapat, dan tindakan orang lain yang berlainan dengan dirinya. Toleransi merupakan sikap menerima sepenuh hati akan keberadaan perbedaan latar belakang agama, suku bangsa, dan budaya yang dimilikinya. Pembiasaan untuk membentuk karakter toleransi di Ponpes Nurul Amal dengan membiasakan peserta didik untuk menghargai perbedaan, menghargai pendapat, tidak mengejek, dan tidak membeda-bedakan teman.

14) Pembiasaan komunikatif 
Komunikatif merupakan tindakan senang berbicara, bergaul, dan bekerjasama dengan orang lain. Pembiasaan agar peserta didik memiliki karakter komunikatif di Ponpes Nurul Amal antara lain pembiasaan mengucapkan salam, sopan santun, tidak sombong, minta izin ketika keluar majelis, hormat kepada semua orang, menerima nasihat, dan menghindari permusuhan, dilatih adzan, menyampaikan pendapatnya ketika kegiatan evaluasi, latihan pidato/muhadharah, dan muroja'ah berantai.

15) Pembiasaan tanggungjawab

Tanggung Jawab merupakan perilaku dan sikap seseorang untuk melaksanakan kewajiban dan tugasnya baik terhadap diri sendiri, Allah Swt., masyarakat, lingkungan, dan negara. Karakter ini harus dikembangkan agar seseorang konsekuen dengan kewajiban-kewajibannya. Pembiasaan tanggung jawab antara lain melaksanakan piket kebersihan, melaksanakan tugas dengan baik, menjaga barang milik sendiri dan orang lain.

\section{Hasil Pengembangan Kepribadian dan Karakter Sosial Peserta Didik Melalui Pembiasaan di Ponpes Nurul Amal}

Pengembangan kepribadian dan karakter sosial di Pondok Pesantren Nurul Amal melalui pembiasaan, cukup efektif dalam membentuk kepribadian dan karakter sosial peserta didik. Setelah dilakukan pembiasaan melalui berbagai aktivitas yang berulang-ulang, peserta didik mengalami perubahan perilaku yang cukup menggembirakan. Keberhasilan ini dapat diketahui melalui hasil pemantauan para asatidz dan asatidzah pembimbingnya. Monitoring dilakukan setiap hari kemudian dilapokan kepada mudir pesantren serta disampaikan dalam buku laporan pendidikan kepada orang tua setiap akhir semester.

Pencapaian pengembangan kepribadian peserta didik di Ponpes Nurul Amal, yaitu: a. Akidah yang benar, indikatornya adalah: 1). Beriman kepada rukun iman, 2). Ikhlas, 3). Mensyukuri nikmat. b. Ibadah yang benar, indikatornya adalah: 1). Baik dalam thaharah, 2). Baik dalam shalat, 3). Melaksanakan shaum fardhu, 4). Komitmen dengan adab tilawah, 5). Menyebarluaskan salam, 6). Tidak sungkan adzan, 7). Bersemangat shalat berjama'ah, 8). Melaksanakan qiyamullail, 9). Melaksanakan shaum sunnah, 10). Khusyu dalam membaca Al-Qur'an, 11). Hafal minimal 1 juz Al-Qur'an, 12). Komitmen dengan wirid harian, 13). Berdo'a, 14). Merutinkan dzikir pagi dan petang. c. Akhlakul karimah, indikatornya adalah:, 1). Rendah hati, 2). Jujur, 3). Tidak mencaci maki, 4). Tidak membicarakan keurukan orang lain, 5). Tidak memotong pembicaraan orang lain, 6). Tidak mencibir, 7). Tidak menghina dan meremehkan orang lain, 8). Menyayangi yang kecil, 9). Menghormati yang besar, 10). Melaksanakan adab Islami. d. Mandiri, indikatornya adalah 1). Melakukan sendiri berbagai kepentingan pribadinya, 2). Menunaikan hak orang lain, 3). Menjaga fasilitas umum. e. Berwawasan luas, indikatornya adalah 1). Baik dalam membaca dan menulis, 2). 
Mengetahui hukum thaharah, shalat, shaum, 3). Rajin membaca, 4). Menjadi pendengar yang baik, 5). Mengemukakan pendapatnya. f. Badan sehat, indikatornya adalah 1). Bersih badan, pakaian,dan tempat tinggal, 2). Olah raga, 3). Bangun sebelum fajar, 4). Komitmen dengan adab makan dan minum sesuai sunnah, 5). Menghindari tempat-tempat kotor. g. Melawan hawa nafsu, indikatornya adalah 1). Memperbaiki penampilan, 2). Bersemangat dalam melaksankan urusannya, 3). Rela berkorban. h. Teratur dalam urusan, indikatornya adalah 1). Memperbaiki penampilan, 2). Bersemangat dalam melaksankan urusannya, 3). Rela berkorban. i. Menjaga waktu, indikatornya adalah memanfaatkan waktu untuk kebaikan. j. Bermanfaat bagi orang lain, indikatornya adalah 1). Membantu yang membutuhkan, 2). Melaksanakan hak orang lain.

Capaian karakter sosial peserta didik di Pondok Pesantren Nurul Amal Ciamis. Secara spesifik, karakter sosial tersebut adalah: a. Peduli sosial indikatornya adalah 1). Membantu orang lain dalam bentuk materi, tenaga, dan pikiran, 2). Menegur dan mengingatkan teman ketika melakukan kesalahan. b. Peduli lingkungan indikatornya adalah 1). Menjaga kebersihan, kerapian asrama dan halamannya, 2). Membuang sampah pada tempatnya, 3). Menyimpan pakaian kotor tempat yang telah disediakan, 4). Melakukan piket harian dan kerja bakti. c. Toleransi indikatornya adalah 1). Mengakui adanya perbedaan, suku, adat istiadat, status sosial dan ekonomi, 2). Menjalankan aktivitas ibadah tanpa menyinggung orang lain, 3). Tidak memaksakan pendapat/ide kepada orang lain. d. Komunikatif indikatornya adalah 1). Mengucapkan salam, 2). Bertutur kata dengan sopan teman dan asatidz/asatidzah, 3). Berkata dan berperilaku sopan dan tidak menyombongkan diri, 4). Mohon izin ketika keluar majelis, 5). Bersikap hormat kepada warga pesantren, 6). Menerima nasehat guru, 7). Menghindari permusuhan perkelahian dengan teman. e. Tanggung jawab indikatornya adalah 1). Melaksanakan tugas sesuai dengan kemampuan, 2). Menjaga kepercayaan yang diberikan, 3). Menjaga barang milik sendiri dan orang lain

\section{Kesimpulan}

Berdasarkan hasil penelitian melalui wawancara, dokumentasi, dan observasi, peneliti dapat mengambil kesimpulan yakni: (1) Pondok Pesantren Nurul Amal Ciamis telah melaksanakan pengembangan kepribadian dan karakter sosial. Manajemen yang dilakukan untuk program ini adalah perencanaan, pelaksanaan dan hasil. Perencanaan pengembangan kepribadian dan karakter sosial di Pondok Pesantren Nurul Amal Ciamis dilaksanakan pada awal tahun pembelajaran yang dirumuskan oleh bidang kurikulum, bidang kesantrian, dan bidang ekstrakulikuler selanjutnya akan diputuskan dalam musyawarah pengurus dan disetujui oleh mudir pesantren. Hal yang termasuk perencanaan adalah kurikulum, program kegiatan, tata tertib, penyiapan SDM pendidik dan penyediaan sarana prasarana. (2) Pelaksanaan 
pengembangan kepribadian dan karakter sosial di Ponpes Nurul Amal dilakukan oleh seluruh asatidz/asatidzah melalui pembiasaan. Hal-hal yang dibiasakan dalam pengembangan kepribadian adalah pembiasaan dalam akidah yang benar, pembiasaan dalam ibadah yang benar, pembiasaan dalam akhlakul karimah, pembiasaan mandiri, pembiasaan dalam berwawasan luas, pembiasaan agar berbadan sehat, pembiasaan dalam melawan hawa nafsu, pembiasaan teratur dalam urusan, dan pembiasaan bermanfaat untuk orang lain. Adapun pembiasaan yang dilakukan untuk mengembangkan karakter sosial adalah peduli sosial, peduli lingkungan, toleransi, komunikatif, dan tanggungjawab. (3) Hasil pengembangan kepribadian dan karakter sosial dapat dilihat dari perilaku peserta didik melalui pemantauan oleh para asatidz dan asatidzah. Para pembimbing melaporkan hasil evaluasinya pada mudir pada rapat pekanan dan bulanan. Selanjutnya mudir menyampaikan laporannya pada pengasuh pesantren. Laporan capaian akademik dan prilaku peserta didik disampaikan kepada orang tua melalui buku raport yang diserahkan pada akhir pembelajaran. Pengembangan kepribadian dan karakter sosial melalui pembiasaan efektif membentuk kepribadian peserta didik dengan karakteristik akidah yang benar, ibadah yang benar, memiliki akhlakul karimah, mandiri, berwawasan luas, berbadan sehat, melawan hawa nafsu, teratur dalam urusannya, menjaga waktu, dan bermanfaat bagi orang lain. Sedangkan karakter sosial yang terbentuk adalah peduli sosial, peduli lingkungan, toleransi, komunikatif, dan tanggungjawab.

\section{DAFTAR PUSTAKA}

Al-Hamdani, D. (2018). Pendidikan Bernuansa Islam. Bandung: Media Cendekia Publisher.

Amrah, S. (2018). Karakter Rabbani Sebagai Medium Pembentukan Kecerdasan Spiritual Dalam Proses Pembelajaran (Sebuah Analisis Empiris Pada Sdit Kota Palopo). El-Tarbawi. https://doi.org/10.20885/tarbawi.vol11.iss1.art1

Anwar, S., \& Salim, A. (2019). Pendidikan Islam dalam Membangun Karakter Bangsa di Era Milenial. Al-Tadzkiyyah: Jurnal Pendidikan Islam. https://doi.org/10.24042/atjpi.v9i2.3628

Az-Zatani, A. H. A. (1994). Asas Tarbiyah Al-Islamiyah Fii Sunnati Nabawiyyah. Libiya: Darul Arabiyah Lil Kitab.

Cahyaningrum, E. S., Sudaryanti, S., \& Purwanto, N. A. (2017). Pengembangan Nilai-Nilai Karakter Anak Usia Dini Melalui Pembiasaan Dan Keteladanan. Jurnal Pendidikan Anak. https://doi.org/10.21831/jpa.v6i2.17707

Echols, J.M., \& Shadily, H. 2003. Kamus Inggris Indonesia. Jakarta: Gramedia 
Fuad, M. (2019). Model Pengembangan Kepribadian di Pesantren.Proceeding of International Comference on Da'wa and Communication (369-382). Surabaya: UIN Sunan Ampel.

Haeruddin, H., Rama, B., \& Naro, W. (2019). Implementasi Pendidikan Karakter di Pondok Pesantren An- Nurîyah Bonto Cini' Kabupaten Jeneponto Provinsi Sulawesi Selatan. Jurnal Pendidikan Agama Islam AlThariqah. https://doi.org/10.25299/al-thariqah.2019.vol4(1).3203

Helmy, M. I. (2019). Kepribadian dalam Perspektif Sigmund Freud dan AlQur'an: Studi Komparatif. Nun: Jurnal Studi Alquran Dan Tafsir Di Nusantara, 4(2), 105. https://doi.org/10.32495/nun.v4i2.69

Hidayat, A. (2018). Psikologi dan Kepribadian Manusia: Perspektif Al-Qur'an Dan Pendidikan Islam. Jurnal Penelitian, 11(2), 467-486. https://doi.org/10.21043/jupe.v11i2.3488

Hidayat, T., Rizal, A. S., \& Fahrudin, F. (2018). Pendidikan Dalam Perspektif Islam Dan Peranannya Dalam Membina Kepribadian Islami. Jurnal MUDARRISUNA: Media Kajian Pendidikan Agama Islam, 8(2), 218. https://doi.org/10.22373/jm.v8i2.3397

Hutagalung, I. (2007). Pengembangan Kepribadian. Jakarta: PT. Indeks.

Idris, D. M., \& Usman, U. (2019). Peranan Pendidikan Akhlak dalam Mengembangkan Kepribadian Peserta Didik di Madrasah Aliyah Negeri 1 Parepare. Al-Musannif.

Kementrian Agama RI. (2007). Al-Qur'an Tajwid dan Terjemah. Jakarta: Sygma exagrafika.

Lathifah, Z. K., \& Rusli, R. K. (2019). Pembiasaan Spiritual Untuk Meningkatkan Pendidikan Karakter Peserta Didik. Tadbir Muwahhid. https://doi.org/10.30997/jtm.v3i1.1649

Maharani, B. (2018). Membangun Karakter Siswa melalui Kompetensi Kepribadian Guru Berbasis Prososial Behaviour. Briliant: Jurnal Riset Dan Konseptual. https://doi.org/10.28926/briliant.v3i4.125

Nata, A. (2012). Ilmu Pendidikan Islam. Jakarta: Kencana Prenada Media Grup.

Poewadarminta. (2007). Kamus Umum Bahasa Indonesia. Jakarta: Balai Pustaka.

Rahim, A., \& Setiawan, A. (2019). Implementasi Nilai-nilai Karakter Islam Berbasis Pembiasaan Siswa di Madrasah Tsanawiyah Negeri Kota Batu. SYAMIL: Jurnal Pendidikan Agama Islam (Journal of Islamic Education). https://doi.org/10.21093/sy.v7i1.1715

Rusmaini. (2017). Manajemen Pendidikan Karakter di Lembaga Pendidikan Islam. El Idare, 2 2, 132-147. http://jurnal.radenfatah.ac.id/index.php/El-Idare

Satori, D. \& Komariah, A. (2009). Metodologi Penelitian Kualitatif. Bandung: Alphabet

Shoimah, L., Sulthoni, \& Soepriyanto, Y. (2018). Pendidikan Karakter Melalui Pembiasaan di Sekolah Dasar. Jurnal JKTP Universitas Negeri Malang, 
1(2), 169-175. http://journal2.um.ac.id

Silahudin, A. (2019). Perbandingan Konsep Kepribadian Menurut Barat Dan Islam. Al-Fikra: Jurnal Ilmiah Keislaman, 17(2), 249. https://doi.org/10.24014/af.v17i2.6343

Sugiharto, R. (2017). Pembentukan Nilai-Nilai Karakter Islami Siswa Melalui Metode Pembiasaan. Educan: Jurnal Pendidikan Islam. https://doi.org/10.21111/educan.v1i1.1299

Supiana, S., Hermawan, A. H., \& Wahyuni, A. (2019). Manajemen Peningkatan Karakter Disiplin Peserta Didik Melalui Kegiatan Ekstrakurikuler. Jurnal Isema: Islamic Educational Management. https://doi.org/10.15575/isema.v4i2.5526

Tafsir, A. (2016). Ilmu Pendidikan Islam Bandung: PT. Rosdakarya..

Tetep. (2017). Menggali Nilai-Nilai Karakter Sosial Dalam Meneguhkan Kembali Jati Diri Ke-Bhineka-an Bangsa Indonesia, 372-379.

Ulwan, A. N. (1984). Pedoman Pendidikan Anak Dalam Islam. Semarang: AsySyifa'.

Undang-Undang Republik Indonesia Nomor 20 Tahun 2003 Tentang Sistem Pendidikan Nasional. (2003). Jakarta: PT. Kloang Klode Putra Timur.

Utami, S. W. (2019). Penerapan Pendidikan Karakter Melalui Kegiatan Kedisiplinan Siswa. Jurnal Pendidikan (Teori Dan Praktik). https://doi.org/10.26740/jp.v4n1.p63-66

Wardati, Z. (2019). Peran Guru dalam Pembentukan Karakter Sosial Anak pada Habib Alby Home Schooling. DAYAH: Journal of Islamic Education. https://doi.org/10.22373/jie.v2i2.4185

Zubaedi. (2011). Desain Pendidikan Karakter Konsepsi dan Aplikasinya Dalam Lembaga Pendidikan. Jakarta: Kencana Prenada Media Grup.

https://news detik.com edisi 02 Mei 2019. Diakses tanggal 6 April 2020

https://surabaya.tribunnews.com edisi 22 September 2019. Diakses tanggal 6 April 2020

https://liputan6.com edisi 5 Desember 2019. Diakses tanggal 6 April 2020 https://Health detik.com edisi 9 Oktober 2018. Diakses tanggal 7 April 2020 https://tirti.id. Com edisi 18 Pebruari 2020. Diakses tanggal 7 April 2020 